The United States has established MPAs in two of these areas: the Papahānaumokuākea protected zone and one in the Mariana Trench in the western Pacific. In late November, Australia proposed plans for a 990,000-square-kilometre reserve in the Coral Sea off the country's northeast coast. Another of the sites highlighted by Pew was New Zealand's Kermadec Islands, where protections are currently in place for the sea floor, and conservationists would like to extend them to the entire water column.

Jay Nelson, director of the global ocean legacy programme at Pew, sees the Papahānaumokuākea MPA as the marine equivalent of Yellowstone National Park, the first big parcel of land to be set aside as a reserve. The creation of that park in 1872, he says, set off a chain reaction, prompting other countries to establish large parks of their own. "That had a similar effect to what Papahānaumokuākea has had in the oceans."

Countries have picked up the pace of establishing reserves as the deadline approaches for the 2012 target. In 2008, Daniel Pauly, a fisheries biologist at the University of British Columbia in Vancouver, Canada, estimated that 2.35 million square kilometres of ocean had been protected $^{2}$. In late 2010, a report from the United Nations Environment Programme (UNEP) and the International Union for Conservation of Nature and Nature Conservancy charities put the area at 4 million square kilometres, with the number of MPAs nearing 5,900.

That area represents just $1.17 \%$ of the world's seas. So the deadline for reaching $10 \%$ was extended to 2020 at last year's meeting of countries that have signed up to the UN Convention on Biological Diversity.

The recent spike in protected areas has Pauly feeling hopeful, despite the failure to meet the 2012 target. "Maybe vast areas of the ocean will be put under protection in time to prevent bad things from happening," he says.

\section{RESERVES WORK}

Scientists and conservationists agree that a good MPA can make a difference. In 2009, Sarah Lester, a marine ecologist at the University of California, Santa Barbara, and her colleagues examined published peerreviewed reports on 124 no-take marine reserves in 29 countries $^{3}$. They found documented increases in characteristics such as biomass, species richness and population size within the boundaries of the reserves.

"By and large, everyone agrees that MPAs can achieve their conservation goals if they are enforced," says Benjamin Halpern, a co-author on the study and director of the Center for Marine Assessment and Planning at Santa Barbara.

But many MPAs are worth little more than the paper they are written

\section{FENCING THE SEA}

Several giant marine reserves have been created in the past decade, including the five biggest ones with protection from sea floor to the ocean surface.

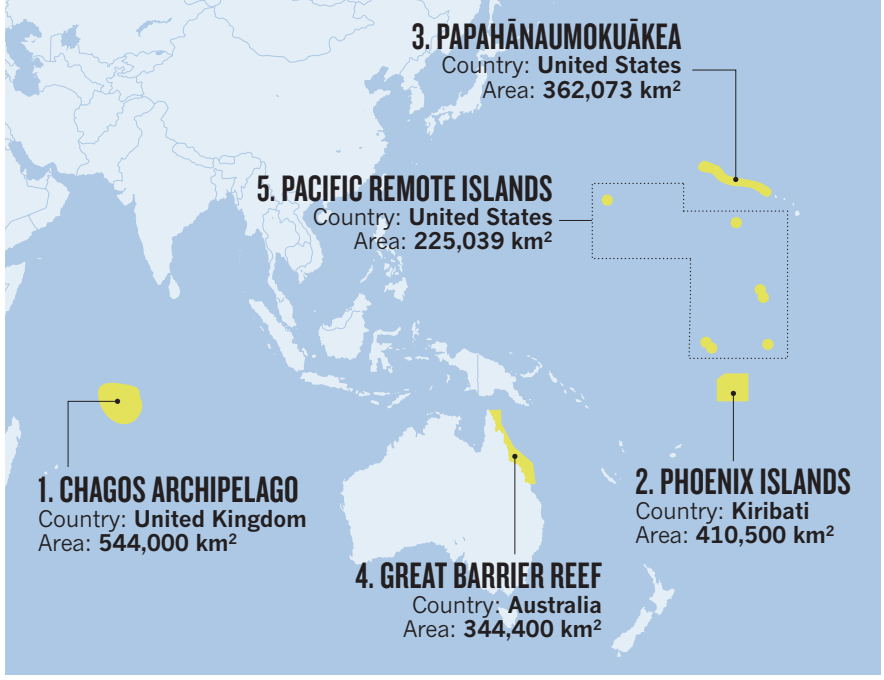

on because nothing is done to enforce the rules or monitor the area. Earlier this year, Peter Jones, an MPA researcher at University College London, and his colleagues produced a report ${ }^{1}$ for UNEP analysing the governance of 20 MPAs, including those in iconic regions such as the Great Barrier Reef and the Galapagos. The team found that none of the MPAs rated more than three out of five points for their effectiveness at meeting key objectives, such as preserving biodiversity and fostering sustainable use of resources. "Three of the 20 MPAs we've said had no effectiveness whatsoever - completely paper parks," Jones says.

Of these, Baleie Franca in Brazil and the Cres-Lošinj reserve in Croatia scored one. Pirajubaé in Brazil scored zero, in part because the government approved a highway in the area that harmed coastal habitats and fishing grounds, the report says.

Even countries that do try to regulate their MPAs can find it hard to fund them. "We don't have the resources that we need to actually monitor, enforce and understand these areas," says Jane Lubchenco, head of the US National Oceanic and Atmospheric Administration.

Poor planning can also hamper an MPA. Mexico, for example, set aside parts of the Gulf of California to protect the endangered vaquita - Phocoena sinus, a type of porpoise - but did not include a large part of the species' range.

The Australian government has also been criticized over its efforts at marine zoning. In August, a group of 173 scientists published an open letter warning that a proposed 320,000-square-kilometre reserve off the southwestern coast "fails on the most basic test" by not protecting a representative selection of habitats in the region. Some suggest that Australia's proposal for a Coral Sea MPA faces similar issues (see Nature 480, 14-15; 2011).

In an e-mail to Nature about the southwestern reserve, a spokesperson from the Australian Department of Sustainability, Environment, Water, Population and Communities said that the government has a responsibility to balance social and economic factors along with ecological ones in decisions about conservation. "The department does not accept that there is a lack of protection for valuable habitat in the proposed marine reserves network," said the spokesperson.

Researchers say that there are ways to improve reserve planning. Many nations are now setting up MPAs using a software called Marxan, which uses an algorithm to calculate the areas that should be included in order to protect the most important habitat while minimizing the cost of the reserve. One of the driving forces behind the software, Hugh Possingham, head of the Spatial Ecology Lab at the University of Queensland in Brisbane, Australia, says that the best approach basically amounts to saying "get me $10 \%$ of everything and annoy as few people as possible". Australia used Marxan to design the Great Barrier Reef MPA, which sets aside large fractions of some 70 types of habitat.

Looking forward, researchers want to investigate how best to monitor and manage the increasing numbers of MPAs. As they assess the effectiveness of reserves, scientists sometimes find surprises, such as the fate of the monk seals in Hawaii's Papahānaumokuākea MPA. The seal population has increased outside the protected region but declined inside it, perhaps because sharks have thrived there ${ }^{4}$. Ashley McCrea Strub, a postdoctoral fellow working with Pauly's lab, says that there are very few data on the cost effectiveness of reserves and it will be vital to fill that gap. "That's really the future of where we need to go," she says. "That's an enormously important question."

Some scientists have argued for doing more studies on MPAs before moving forward with major plans for new ones. But Possingham says the benefits in most cases are clear enough. "If you wait till you have perfect data," he says, "then you'll be waiting forever." - SEE EDITORIAL P.151

Daniel Cressey is a reporter with Nature in London.

1. Jones, P. J. S., Qiu, W. \& De Santo, E. Governing Marine Protected Areas: Getting the Balance Right (UNEP, 2011); available at http://go.nature.com/tjyfbw

2. Wood, L. J., Fish, L., Laughren, J. \& Pauly, D. Oryx 42, 340-351 (2008).

3. Lester, S. E. et al. Mar. Ecol. Prog. Ser. 384, 33-46 (2009)

4. Jones, N. Nature http://dx.doi.org/10.1038/news.2011.522 (2011). 